\title{
Tree-Ring Based Reconstructions of Paleo- Precipitation REgIMES IN THE EASTERN YELLOWSTONE REGION
}

\author{
S.T. GRAY $\downarrow$ S.T. JACKSON $\downarrow$ K. TAYLOR $\downarrow$ C. PALMER \\ DEPARTMENT OF BOTANY $\uparrow$ UNIVERSITY OF WYOMING $\uparrow$ LARAMIE \\ C.L. FASTIE $\uparrow$ BIOLOGY DEPARTMENT \\ MIDDLEBURY COLLEGE $\uparrow \mathrm{VT}$
}

\section{$\downarrow$ INTRODUCTION}

There are few other regions where the influence of climate on basic ecosystem attributes has been as well documented as the Greater Yellowstone Ecosystem (GYE). Research has shown that elk, bison, and grizzly bear populations in the GYE are tightly linked to annual climate variation (Meagher 1976, Picton 1978). Authors have shown that the distribution of vegetation types in Grand Teton and Yellowstone National Parks is influenced by the seasonality of precipitation (Despain 1987, 1990). Natural disturbances, especially fires and insect outbreaks, are also known to coincide with specific climate scenarios in this region (Knight 1987, Balling et al. 1992). Therefore, understanding how climate can vary over time is essential for the proper management of these areas (Luckman 1996).

Modern instrumental records have contributed greatly to our understanding of the current GYE climate system. In particular, work by Mock (1996) and Bartlein et al. (1997) has demonstrated how local manifestations of large-scale circulation patterns produce distinct climates within the GYE. In addition, studies using modern climate records and General Circulation Models by Balling et al. (1992) and Bartlein et al. (1997) have identified trends toward increasing aridity in the GYE and the potential for these trends to continue well into the future.
Late Pleistocene and Holocene (18-1 kya) climate in the GYE is known mainly from lakesediment cores. Work by Whitlock (1993), Whitlock and Bartlein (1993), and Thompson et al. (1993) indicates that after deglaciation, increased solar radiation during summer months led to a highly seasonal climate regime. As levels of solar radiation changed through the Holocene, GYE climate became increasingly more like today until the modern regime became established around 1500-1600 AD (Whitlock 1993, Elias 1997).

While existing modern and paleoecological studies reveal important aspects of the GYE climate system, there is a distinct lack of high-resolution data for most of the last millennium. Lake sediments only record climate variation at a resolution of hundreds to thousands of years, and instrumental records do not exist before the 1890s. Dendroclimatology, the study of climate using patterns of tree-ring growth (Fritts 1976 ) is particularly well suited to fill this gap in our knowledge of GYE climate.

Tree-rings have been used successfully for climate reconstructions worldwide, offer records spanning decades to millennia, and can provide annual resolution. Therefore, we are developing a network of tree-ring sites in the western Absaroka Mountains and eastern Bighorn Basin to fill important spatial (areas east of Yellowstone NP) and 
temporal (high resolution for the past 700-1,000+ year) gaps in our knowledge of GYE climate.

\section{METHODS}

\section{Field Techniques:}

During the summer 2000 field season, we sampled trees from three sites in the Absaroka Mountains (Figure 1). Two sites, Stagecoach and Crosby Mountain, were located along the Wood River about $60 \mathrm{~km}$ west of Meeteetse, Wyoming. The third site was located on Carter Mountain southwest of Cody, Wyoming. Multiple cores were taken from 86 Pinus flexilis (limber pine) trees (live and dead) at the Absaroka area sites. All three sites have an elevation near 8700'. All cores were collected from trees growing on effectively dry substrates such as bare rock or talus.

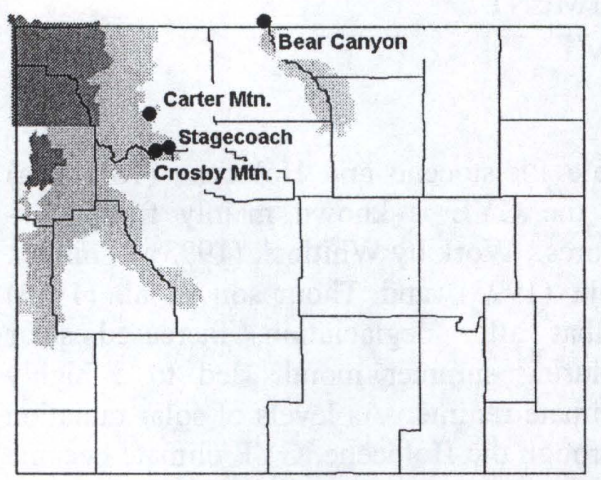

Figure 1. Map of study site locations. National Forest (light gray) and National Park (dark gray) lands are also shown. Figure 1. Map of study site locations. National Forest (light gray) and National Park (dark gray) lands are also shown.

\section{Dating and Measurement of Cores:}

In the laboratory, we dried, mounted, and progressively sanded all cores to at least 400 grit (Cook and Kairiukstis 1990, Grissino-Mayer 1996). Exact dates were assigned to each ring using standard crossdating methods (Stokes and Smiley 1968, Swetnam et al. 1985). We then measured all rings from the dated series to the nearest $0.01 \mathrm{~mm}$ using a computer-based optical measuring device. Dating accuracy was confirmed using the COFECHA program (Holmes 1983).

As tree diameter increases with age, ring width generally decreases since a year's growth must be spread over a larger area (Fritts 1976). This growth artifact must be removed through the process of standardization before the climate signal can be extracted. We used the CRONOL program (Holmes 1992) to standardized ring widths from each dated series and assemble these series into a site chronology consisting of the average ring-width index value for each year.

\section{Reconstructing Climate from Tree Growth:}

We used correlation analysis to compare modern meteorological records with standardized tree-ring widths produced during the same time period (Fritts 1976). Both individual weather station records and regionalized data were examined. Since tree growth can be impacted by climate over a period extending to the previous year's growing season, we also constructed seasonal variables for comparison (Grissino-Mayer 1992).

\section{RESULTS AND DISCUSSION}

We developed records ranging from 8011126 years in length from the Absaroka mountain sites (Table 1). The ring widths from these sites are significantly $(\mathrm{p}<0.01)$ correlated with regional and local growing season moisture. More specifically, these ring-width records are correlated with summer drought indices (Palmer Drought Severity Index) in Wyoming Climate divisions 1,2 and 4 (the Yellowstone, Snake and Bighorn drainages, respectively) and spring, summer and annual precipitation for individual climate stations in the western Bighorn Basin. Pearson correlation values range from $\mathrm{r}=0.3$ to $\mathrm{r}=0.55$. Ring width measurements are also highly correlated between sites $(p<0.01, r>0.5)$, indicating a strong regional forcing on the growth of these trees.

\begin{tabular}{|llc|}
\hline \multicolumn{3}{|l|}{$\begin{array}{l}\text { Table 1. Sites sampled during summer } 2000 \text { with location } \\
\text { (Lat/Lon) and length of record. }\end{array}$} \\
\hline \multicolumn{2}{|c|}{ Location } & Years in Record \\
\hline Carter Mountain & $44 \square 19^{\prime}, 109 \square$ & 801 \\
& $16^{\prime}$ & \\
Stagecoach & $43 \square 56^{\prime}, 109 \square$ & 1126 \\
& $12^{\prime}$ & \\
Crosby Mountain & $43 \square 56^{\prime}, 109 \square$ & 879 \\
& $14^{\prime}$ & \\
\hline
\end{tabular}

In some cases these records may fail to capture high frequency, year to year variations in climate (Figure 2). This may be due in large part to these sites location on the border of three state climate divisions and their distance from climate 
stations (Figure 3). However, smoothing to remove extreme year to year variations shows that these chronologies capture lower frequency, multi-year to decadal trends very well (Figure 4). Overall, the relationship between these chronologies and modern climate records, along with the strong relationship between ring-widths at each site indicate that these records are a good proxy for regional drought.

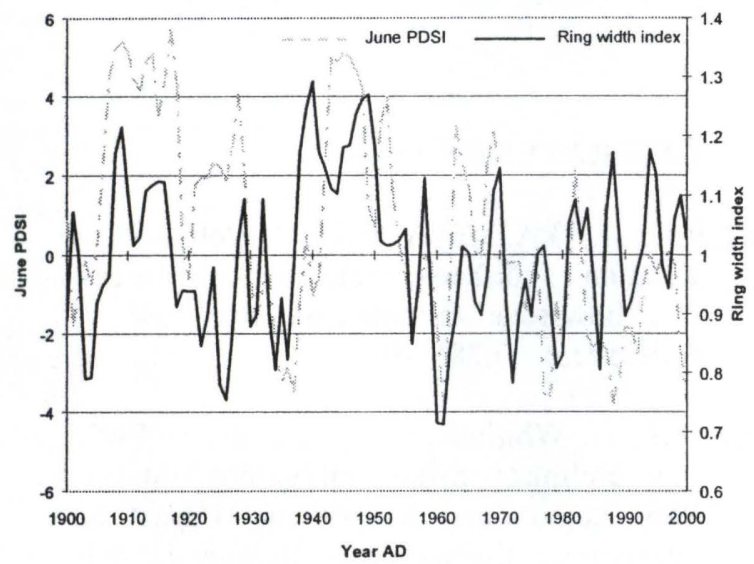

Figure 2. The Carter Mountain limber pine chronology and Wyoming Climate Division 1 June PDSI (Palmer Drought Severity indices). Ring-widths at the $\mathrm{A}$ bsaroka a rea sites a re significantly correlated with summer PDSI values from the surrounding regions.

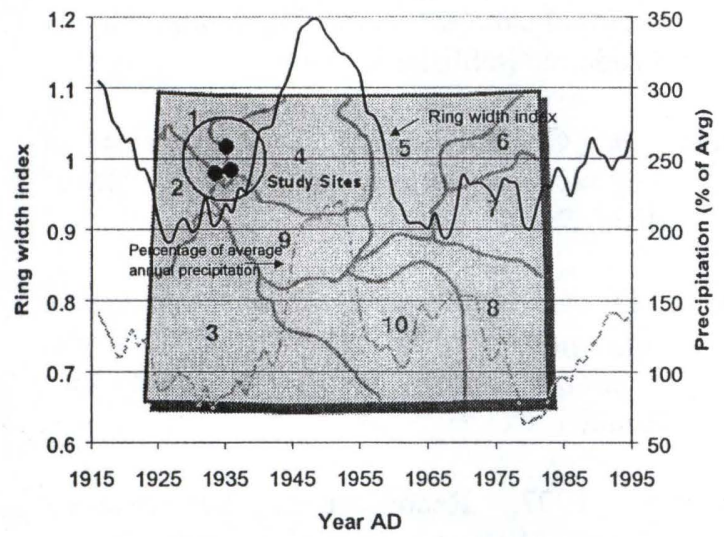

Figure 3. Wyoming Climate Divisions and tree-ring study sites. All three study sites sit on the boundaries between Wyoming Climate Divisions 1,2,4 and 9.

Figure 4. Comparison of ring-width index values from the Carter Mountain limber pine chronology and the percentage of average annual precipitation (percentage of $100 \mathrm{yr}$ average) recorded at climate stations in the western Bighorn Basin over the same period. Data are smoothed using a 5-year moving average to highlight multi-year (low frequency) variations.

With 18 trees spanning the $1800-2000 \mathrm{AD}$ portion of the record and 6 trees dated back to 1350 , the Carter Mountain site represents the most completely developed chronology from our Absaroka
Mountains study area. Several severe, multi-year droughts are recorded in this chronology during the period 1350-2000 (Figure 5). In particular, droughts during the periods from roughly $1370-1390,1590$ $1610, \quad 1650-1660$ and $1730-1760$ surpass any droughts seen in the $20^{\text {th }}$ Century in both duration and magnitude. These same droughts are also reported from records in the Northern Great Plains. While this strengthens our assertion that these chronologies record regional drought, it also points to the potential for devastating, widespread droughts striking both the Great Plains and Rocky Mountain West simultaneously. When the Carter Mountain chronology is compared with records from our sites in the Bighorn Mountains (Fastie et al. in prep), we see severe droughts occurring more or less simultaneously during the period from $1500-2000$ in these two areas (Figure 6). Before 1500 drought events become more a synchronous, but this may be an artifact of low sample depth $(n=6)$ in the Carter Mountain chronology for this period.



Figure 5. The Carter Mountain limber pine chronology. Ringwidth values above 1 correspond to wet episodes while values below 1 indicate drought conditions. Both the annual ringwidth record and a 25 -year smoothing (moving average) are shown. Major droughts reported in Woodhouse and Overpeck (1998) and Stahle et al. (2000) are also shown.

When we compare fire history records from Yellowstone National Park (Romme and Despain 1989) with our Carter Mountain chronology, we see that active burn periods tend to follow prolonged wet events. In particular, two of the three most active burn periods from $1690-1870$ follow the wettest events recorded in the Carter Mountain chronology (Figure 7). The 1730-1750 burn period, the second worst in the prehistoric period, follows a moderate wet $\mathrm{e}$ vent, but a lso $\mathrm{c}$ oincides with a major d rought. Overall, these data suggest that both fuel buildup during moist years and extreme dry conditions contribute to major fires. 


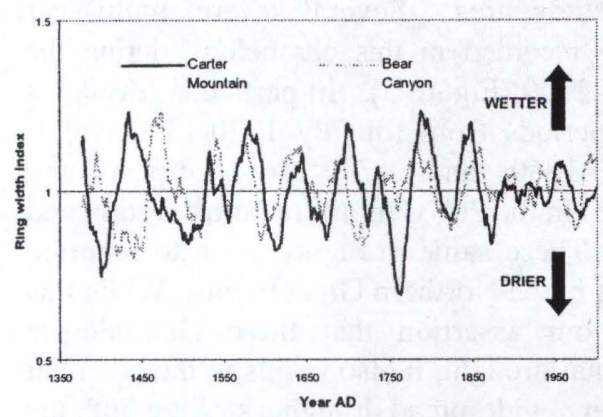

Figure 6. Comparison of the Carter Mountain and Bear Canyon (See Figure 1 for location) limber pine chronologies. Data are smoothed using a 25 -year moving average. Ring-width values above 1 correspond to wet episodes while values below 1 indicate drought conditions.

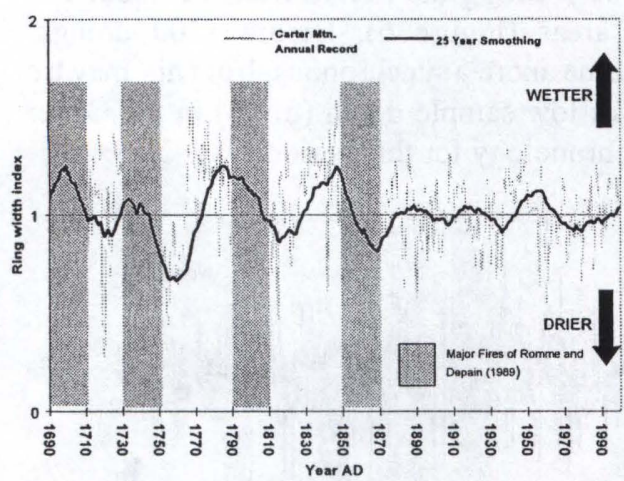

Figure 7. Comparison of major GYE burn periods and the Carter Mountain limber pine chronology. Major burn periods represent 20-year intervals when at least $10 \%$ of Romme and Despain's (1989) 320,000 acre study area burned.

\section{CONCLUSIONS}

As we continue to build and strengthen these chronologies, this project promises a detailed reconstruction of climate dynamics during the past 700-1,000+ years for portions of the GYE east of Yellowstone National Park. This period is particularly important since current precipitation regimes are thought to have developed after $1500 \mathrm{AD}$ (Whitlock 1993, Elias 1997). While dendroclimatic reconstructions for this time period have begun elsewhere in the GYE, almost no effort has been made to understand the past climate dynamics of our study area. Furthermore, comparisons between our paleo-climate records and reconstructions of prehistoric burns in the GYE may yield further information on the relationship between climate and fire.

Overall, these records show that the climate of the $20^{\text {th }}$ Century was relatively mild in comparison to periods in the past. Therefore, any drought response strategies based on the $20^{\text {th }}$ Century climate record cannot account for the full range of drought severity and duration we should expect. Furthermore, based on comparisons between our climate reconstructions and those from the Bighorn Basin and northern Great Plains, the most severe droughts may also tend to be the most widespread. Anyone with an interest in fires, wildlife and agriculture in the eastern GYE must consider these facts when planning for the management of these areas.

\section{Literature Cited}

Balling, R.C., Jr., G.A. Meyer, and S.G. Wells. Relation of surface climate and burned areas in Yellowstone National Park. Agri. and Forest Met. 60:285-293.

Bartlein, P.J., C. Whitlock, and S.L Shafer. 1997. Future climate in the Y ellowstone $\mathrm{N}$ ational Park Region and its potential impact on vegetation. Conservation Biology, 11:782792.

Cook, E. and L. Kairiukstis. 1990. Methods of dendrochronology: Applications in the environmental sciences. Dordrecht, Kluwer Academic Publishers, 394 p.

Despain, D. G. 1987. The two climates of Yellowstone National Park. Proc. Mont. Acad. Sci. 47: 11-19.

Despain, D. G. 1990. Yellowstone vegetation: consequences of environment and history in a natural setting. Roberts Rinehart, Inc., Boulder, CO.

Elias, S.A. 1997. Reconstructing Yellowstone's Climate History. Yellowstone Science, 5:28.

Fastie, C.L., S.T. Gray, S.T. Jackson, and J.L. Betancourt. in prep. Late Holocene climate variation inferred from tree-rings in the Bighorn Mountains of Wyoming, USA.

Fritts, H.C. 1976. Tree rings and climate. Academic Press, London, $576 \mathrm{p}$. 
Grissino-Mayer, H.D. 1996. A 2129 year reconstruction of precipitation for northwestern New Mexico, USA. In: Dean, J.S., D.M. Meko, and T.W. Swetnam, eds. Tree rings, environment, and humanity. Radiocarbon 1996. University of Arizona, Tucson, AZ. pp.191-204.

Holmes, R.L. 1983. Computer-assisted quality control in tree-ring dating and measurement. Tree-Ring Bulletin, 43:69-78.

Holmes, R.L. 1992. CRONOL. In: Grissino-Mayer, H.D., R.L. Holmes and H.C. Fritts, eds. User's manual for the International TreeRing Data Bank Program Library. Laboratory of Tree-Ring Research, Tucson, Arizona, pp. 64-69.

Knight, D.H. 1987. Parasites, lightning and the vegetation mosaic in wilderness landscapes. In M.G. Turner ed. Disturbance and Landscape Heterogeneity. Springer-Verlag, New York, pp. 57-83.

Luckman, B.H. 1996. Dendrochronology and Global Change. In: Dean, J.S., D.M. Meko, and T.W. Swetnam, eds. Tree rings, environment, and humanity. Radiocarbon 1996. University of Arizona, Tucson, AZ. pp3-24.

Meagher, M. M. 1976. Winter weather as a population-regulating influence on freeranging bison in Yellowstone National Park. In: Reid, N. J. ed. National Park Service Symposium series, no. 1, 29-38. 1976. Washington, DC. U.S. Department of the Interior. 12-28-1971.
Mock, C.J. 1996. Climatic controls and spatial variations of precipitation in the western United States. Journal of Climate, 9:11111125.

Picton, H.D. 1978. Climate and reproduction of grizzly bears in Yellowstone National Park. Nature, 274: 888-889.

Romme, W.H. and D.G. D espain. 1989. The long history of fire in the Greater Yellowstone Ecosystem. Western Wildlands, 15:10-18.

Stokes, M.A. and T.L. Smiley. 1968. An introduction to tree-ring dating. The University of Chicago Press, Chicago, $73 \mathrm{p}$.

Swetnam, T.W., M.A. Thompson, and E.K. Sutherland. 1985. Using dendrochronology to measure radial growth of defoliated trees. USDA Forest Service Agricultural Handbook \#639. Washington, DC. 39 p.

Thompson, R.S., C. Whitlock, P.J. Bartlein, S.P. Harrison, and W.G. Spalding. 1993. Climatic change in the Western United States since 18,000 yr B.P. In: Wright, H.E, Jr., ed. Global Climates since the Last Glacial Maximum. Univ. of Minnesota Press, Minneapolis, 1993, pp.468-513.

Whitlock, C. 1993. Postglacial vegetation and climate of Grand Teton and southern Yellowstone National Park. Ecol. Monogr. 63:173-198.

Whitlock, C. and P.J. Bartlein. 1993. Spatial variations in climate change in the Yellowstone region. Quat. Res. 39:231-238. 